\title{
TRANSFORMASI GEN ALBUMIN BUNGA MATAHARI (Helianthus annuuss L.) DENGAN VEKTOR Agrobacterium tumefaciens SECARA IN PLANTA PADA TANAMAN KEDELAI
}

\author{
SUBERATA, I W. \\ Fakultas Peternakan Universitas Udayana \\ e-mail :suberata@unud.ac.id
}

\begin{abstract}
ABSTRAK
Penggunaan A. tumefaciens untuk maksud mengintroduksi DNA albumin bunga matahari ke dalam sel tanaman kedelai didasari atas kemampuan alami dari A.tumefaciens untuk mentransfer suatu fragmen yang spesifik dari DNA plasmid (T-DNA ) ke dalam sel tanaman lalu berintegrasi pada genom sel tanaman inang. Hasil kloning gen albumin yang ditumbuhkan pada bakteri E.coli selanjutnya ditransfer ke A. tumefaciens LBA $_{4404}$ melalui metode triparental mating. A. tumefaciens $\mathrm{LBA}_{4404}\left(\mathrm{pAL}_{4404}, \mathrm{pSW}_{600}\right)$ yang dihasilkan kemudian ditransformasikan pada tanaman kedelai secara in planta. Hasil analisis transformasi pada tanaman kedelai transgenic secara in planta dapat dibuktikan dengan analisis PCR.
\end{abstract}

Kata kunci: transformasi, albumin bunga matahari, A. tumefaciens, tanaman kedelai

\section{GENE TRANSFORMATION OF ALBUMINE SUNFLOWER (Helianthus annuuss L.) WITH Agrobacterium tumefaciens VECTOR BY IN PLANTA AT SOYBEAN PLANTS}

\begin{abstract}
Usage of A. tumefaciens for the purpose of including DNA sunflower albumine into soybean cell, constituted of natural ability of $A$. tumefaciens to trasformation in specific form of DNA plasmid (T-DNA) into soybean cell, then integrate at mains soybean cell genom. Result of gene cloning of albumine grown at bacterium of $E$. coli, then carried over by $A$. tumefaciens $\mathrm{LBA}_{4404}$, passing method of triparental mating. A.tumefaciens $\mathrm{LBA}_{4404}\left(\mathrm{pAL}_{4404}\right.$, $\mathrm{pSW}_{600}$ ) yielded later, then transformation at soybean by in planta. Result of analysis of transformation at soybean of transgenic by in planta, can be proved with PCR analysis.
\end{abstract}

Key words: trasformation, sunflower albumine, A. tumefaciens, soybean

\section{PENDAHULUAN}

Biji kedelai merupakan sumber utama protein nabati bagi manusia dan hewan karena kandungan proteinnya yang cukup tinggi, bervariasi sekitar $35-50 \%$ berat keringnya. Mengingat perannya yang sangat penting sebagai sumber protein nabati baik bagi manusia dan hewan, maka sangat diperlukan suplai komoditi ini secara berkesinambungan baik dari segi jumlah maupun kualitas protein yang ditentukan oleh proporsi sistein dan metioninnya (Sunarpi dan Anderson, 1997).

Sejauh ini upaya-upaya pemulihan konvensional belum berhasil meningkatkan nilai biologis protein biji kedelai, melalui peningkatan kadar sistein dan metionin pada protein yang dikandungnya. Kegagalan tersebut disebabkan oleh banyak factor, namun yang paling mendasar disebabkan oleh ketidakmobilan belerang terutama dalam bentuk senyawa organik di dalam tubuh tanaman. Karena itu pendekatan rekayasa genetik merupakan upaya yang paling memungkinkan untuk mengatasi masalah tersebut. Salah satu strategi rekayasa yang paling menjanjikan keberhasilannya yaitu dengan cara mentransfer gen asing Sfa8 yang berasal dari bunga matahari yang mengkode protein yang kaya belerang. Transfer gen tersebut telah berhasil berekspresi pada organ vegetatif tanaman alfalfa (Tabe et al., 1995), tanaman vicia (Pickard et al., 1993) dan tanaman semanggi (Rafigul et al., 1993) sehingga transfer genotif tersebut mampu menaikkan kadar sistein dan metionin protein organ vegetatif dan organ generatif tanaman. Namun demikian belum banyak dipublikasikan berekspresinya genotip tersebut pada tanaman, sehingga diperlukan studi yang lebih mendalam mengenai segala faktor yang berpengaruh terhadap keberhasilan berekspresinya gen tersebut di dalam sel tanaman. Dengan adanya indikasi biosintesis 
protein yang kaya sulfur pada biji kedelai, maka tampaknya ada peluang keberhasilan berekspresinya gen Sfa8 ke dalam sel tanaman kedelai (Sunarpi dan Anderson, 1997).

Penggunaan teknik transformasi genetik secara in planta telah menyebar dan banyak diterapkan, karena teknik ini dilakukan tanpa melalui kultur in vitro yang rumit dan biaya yang tinggi. Transformasi dilakukan dengan menginokulasi A. tumefaciens yang membawa plasmid biner dengan klon gen yang dikehendaki pada biji atau bibit tanaman yang masih sangat muda (seedling). Prinsipnya adalah menginokulasi sel-sel meristem atau embrio yang tertransformasi akan tumbuh menjadi tanaman transgenik yang mengandung gen yang tertransformasi melalui vector A. tumefaciens (Wirawan et al., 1996). Dalam teknik ini akan lebih banyak menghasilkan tanaman transgenik yang chimera, artinya tidak seluruh tanaman adalah sel yang tertransformasi tetapi transformasi genetik terjadi hanya secara parsial. Namun biasanya 1 2\% dari tanaman yang dihasilkan adalah transgenik penuh (whole transgenic) artinya setiap sel pada tanaman tersebut adalah sel-sel yang tertransformasi (transformed cell).

Berdasarkan hal tersebut perlu dilakukan studi transfer gen Sfa8 ke dalam sel tanaman kedelai secara in planta dengan harapan dapat menghasilkan tanaman kedelai transgenik yang mampu menaikkan nilai gizi biji kedelai baik sebagai sumber protein bagi manusia maupun pakan ternak yang sekaligus mampu menunjang pembangunan nasional melalui program peningkatan gizi masyarakat.

\section{MATERI DAN METODE}

Penelitian ini dilaksanakan di Laboratorium Bioteknologi dan rumah kaca Jurusan Hama dan Penyakit Tanaman, Fakultas Pertanian Universitas Udayana.

\section{Transformasi Genetik dengan Metode Tripa- rental Mating}

Transformasi genetik dengan metode triparental mating yaitu suatu metode memasukkan plasmid $\mathrm{pBI}_{121}$ dari sel $E$. coli ke dalam sel $A$. tumefaciens dengan bantuan $E$. coli yang mengandung plasmid $\mathrm{pRK}_{2013}$ (Vervliet dalam Wirawan, 1996) seperti yang terlihat pada (Gambar 1).

Prosedur kerjanya adalah sebagai berikut: ketiga bakteri di atas dikultur secara terpisah pada media LB cair dengan antibiotika dan suhu yang sesuai $A$. tumefaciens LBA $\left(\mathrm{pAL}_{4404}\right)$ tanpa antibiotika, $28^{\circ} \mathrm{C}$, E. coli $\left(\mathrm{pBI}_{121}+600 \mathrm{bp} \mathrm{Sfa} 8\right)$ dan E.coli $\left(\mathrm{pRK}_{2013}\right)$ masing-masing dengan $100 \mathrm{ppm}$ kanamisin dan suhu $37^{\circ} \mathrm{C}$. Kemudian diinkubasi pada suhu $37^{\circ} \mathrm{C}$ semalam dengan pengocokan (shaker). Sel bakteri dipanen dengan sentrifugasi pada 5000 rpm selama 1 menit. Sel-sel bakteri dicuci dengan aquades steril (pakai aquabides ) 2 kali. Kemudian sel-sel bakteri disuspen

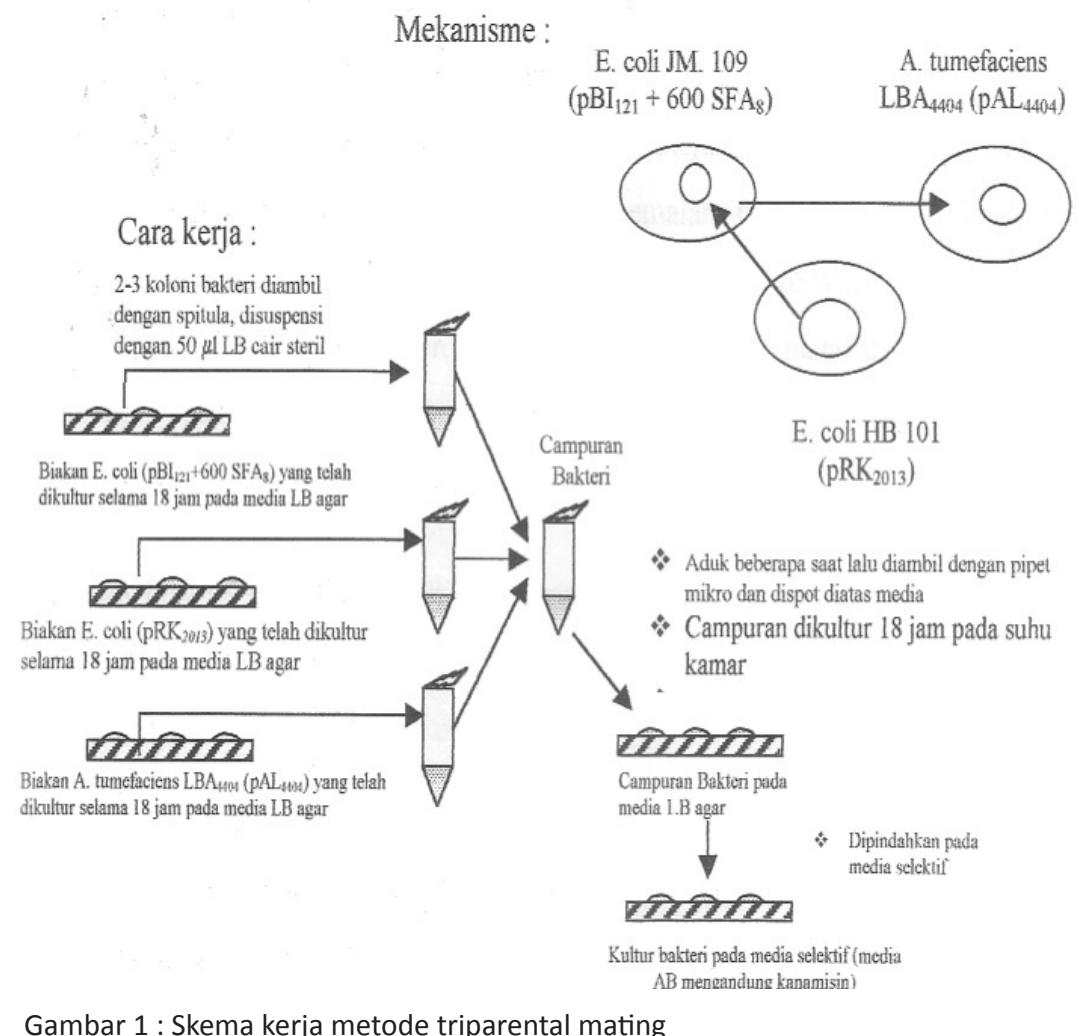


dalam $300 \mu \mathrm{l}$ LB liquid tanpa antibiotika. Masingmasing $100 \mu \mathrm{l}$ suspensi ketiga bakteri dimasukkan ke dalam $1,5 \mathrm{ml}$ eppendorf tube steril, kemudian ketiga bakteri dicampur dengan membalik-balikkan tubenya. Setelah tercampur merata lalu disentrifugasi pada $3000 \mathrm{rpm}$ selama 1 menit. Supernatannya dibuang lalu sel-sel bakteri tersebut disuspensi dalam $100 \mu \mathrm{l}$ LB cair. Sebanyak $30 \mu \mathrm{l}$ suspensi bakteri (campuran ketiganya) diteteskan (spot) di atas media LB agar, kemudian diinkubasi semalam pada suhu $30^{\circ} \mathrm{C}$. Bakteri yang tumbuh diambil dengan kawat ose kemudian dikultur untuk menghasilkan single koloni pada media $\mathrm{AB}$ dengan kanamisin $100 \mathrm{ppm}$. Pada media $\mathrm{AB}$ hanya $A$. tumefaciens yang bisa hidup, sedangkan E. coli tidak bisa hidup. Kemudian dikultur semalam pada suhu $28^{\circ} \mathrm{C}$. Single koloni yang tumbuh adalah A. tumefaciens $\mathrm{LBA}_{4404}\left(\mathrm{pAL}_{4404}+\mathrm{pSW}_{600}\right)$. Dengan demikian klon gen Sfa8 yang fragmennya dapat dari biji bunga matahari telah diklon pada $\mathrm{pBI}_{121}$ dan dipelihara pada sel A.tumefaciens $\mathrm{LBA}_{4404}$, sehingga siap untuk ditransformasikan dalam sel tanaman (kedelai).

\section{Transformasi Genetik Secara in planta}

Penelitian ini dilakukan di rumah kaca, dengan menggunakan media perkecambahan dari polybag yang berisi campuran tanah dan pasir 1:1. Biji kedelai yang akan digunakan direndam dengan aquades selama 15 menit untuk merangsang perkecambahan. Setelah kecambah tumbuh, tunas aksilar dan tunas baru yang tumbuh di atas kotiledon dipotong, kemudian diinokulasi dengan $A$. tumefaciens $\mathrm{LBA}_{4404}\left(\mathrm{pAL}_{4404}\right.$, $\mathrm{pSW}_{600}$ ). Sebagai kontrol, juga ditanam kedelai tanpa diinokulasi dengan A. tumefaciens $\mathrm{LBA}_{4404}$. Setelah 1-2 minggu, tunas baru hasil inokulasi akan tumbuh di atas kotiledon. Untuk keperluan analisis, diambil tunas/daun mudanya apakah sudah tertransformasi $A$. tumefaciens $\mathrm{LBA}_{4404}$, dengan mendeteksi keberadaan gen albumin bunga matahari menggunakan analisis polymerase chain reaction (PCR). Disamping itu juga dilihat perbedaan pertumbuhan dan hasil yang dicapai antara tanaman yang tertransformasi dengan tanaman kontrol.

\section{Analisis Jaringan Transforman}

Untuk membuktikan keberadaan gen albumin pada tanaman kedelai hasil transformasi, dilakukan analisis PCR menggunakan primer spesifik dari Sfa8. Squen primer yang digunakan adalah sebagai berikut:

5' GGGGATCCATGGAAGGTTTTCGATCG 3' dan 5' GGGAATTCCCGGGTTTACATTTGGCATGG 3'

Program PCR yang digunakan adalah:

I). Pre-treatment pada suhu $92^{\circ} \mathrm{C}$ selama 30 detik dengan satu siklus ulangan.

II). a. Denaturation pada suhu $92^{\circ} \mathrm{C}$ selama 60 detik b. Annealing pada suhu $60^{\circ} \mathrm{C}$ selama 30 detik

c. Elongation pada suhu $72^{\circ} \mathrm{C}$ selama 90 detik pada bagian II ini menggunakan 40 siklus ulangan

III). Extention pada suhu $72^{\circ} \mathrm{C}$ selama 10 menit dengan satu siklus ulangan.

\section{HASIL DAN PEMBAHASAN}

\section{Transformasi Klon Gen Albumin pada Plasmid pBI $_{121}$ ke dalam Sel A.tumefaciens LBA $_{4404}$ dengan Metode Triparental Mating}

Transformasi gen albumin bunga matahari pada plasmid $\mathrm{pBI}_{121}$ ke dalam sel $A$. tumefaciens $\mathrm{LBA}_{4404}$ dengan metode triparental mating, setelah ditumbuhkan pada media $\mathrm{AB}$ dengan kanamisin, hasilnya adalah hanya koloni bakteri $A$. tumefaciens $\mathrm{LBA}_{4404}\left(\mathrm{pAL}_{4404}\right.$, $\mathrm{pSW}_{600}$ ) yang bertahan tumbuh pada media seleksi (AB agar + kanamisisn) seperti yang telihat pada Gambar 2 .

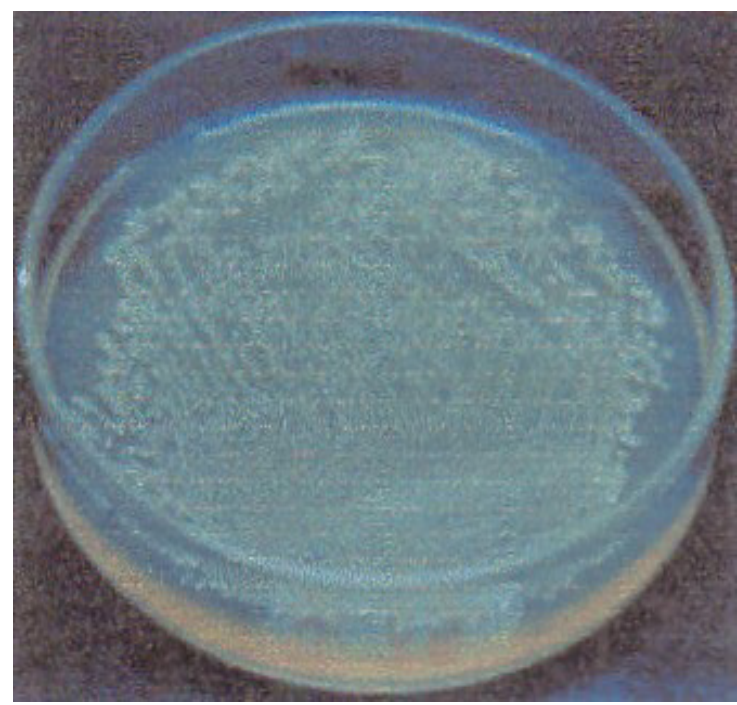

Gambar 2: Pemurnian A. tumefaciens $\mathrm{LBA}_{4404}\left(\mathrm{pAL}_{4404}+\mathrm{pSW} 600\right)$ pada media $A B$ agar + kanamisin umur 3 hari.

Bertahannya A. tumefaciens $\mathrm{LBA}_{4404}\left(\mathrm{pAL}_{4404}+\right.$ $\mathrm{pSW}_{600}$ ) pada media seleksi ( $\mathrm{AB}+$ kanamisin) karena pada media $\mathrm{AB}$ sudah dikondisikan sedemikian rupa sehingga hanya $A$. tumefaciens $\mathrm{LBA}_{4404}$ yang bisa tumbuh, sedangkan bakteri lain seperti $E$. coli akan mati. Sedangkan bertahannya $A$. tumefaciens LBA $_{4404}$ pada media kanamisin, karena adanya $\mathrm{pSW}_{600}$ yang merupakan gabungan antara $\mathrm{pBI}_{121}$ dan gen albumin. Telah diketahui bahwa pBI $_{121}$ mengandung fragmen Npt II, gen GUS dan multi kloning site yaitu fragmen pendek tempat pengklonan gen asing (albumin) untuk ditransfer. Dengan adanya Npt II yang resisten terhadap kanamisin pada $\mathrm{pSW}_{600}$ menyebabkan A. tumefaciens $\mathrm{LBA}_{4404}$ tetap bertahan pada media dengan kanamisin (Wirawan, 1996). 
Pada umumnya penanda genetik yang digunakan pada tanaman, kebanyakan merupakan ensim resisten terhadap antibiotika yang telah direkayasa sehingga dapat diekspresikan secara konstitutif pada tanaman. Sebagai contoh adalah Neomycin phosphotransferase II (Npt II) yang membuat resisten terhadap kanamisin. Kegunaan gen penanda pada beberapa vector trasformasi adalah dapat dengan mudah dilakukan verifikasi terhadap jaringan transformasi pada media yang mengandung antibiotik. (Kort, et al., 1991).

\section{Transformasi Genetik dengan A.tumefaciens ke} dalam Tanaman Kedelai Secara In planta

Hasil penelitian ini disajikan pada (Gambar 3). Sebagaimana telah disajikan pada metodelogi di atas bahwa transformasi genetik dilakukan terhadap kecambah yang telah dihilangkan tunas barunya yang tumbuh di atas kotiledon (Gambar 3a). Pertumbuhan tunas baru diawali dengan baik pada minggu 1-2 setelah inokulasi (Gambar 3b). Tunas-tunas transgenik yang dihasilkan menunjukkan cabang-cabang yang lebih banyak dibandingkan dengan yang tidak terinokulasi yaitu rata-rata 23 cabang per pohon pada tanaman terinokulasi dan 17 cabang pada tanaman kontrol. Ini menunjukkan tanaman yang terinokulasi cabangnya lebih banyak 35,29\% dari tanaman yang tidak terinokulasi. Perbedaan ini sangat jelas terlihat pada tanaman yang sudah menginjak dewasa (Gambar 3c) sehingga buah yang dihasilkan setelah panen menunjukkan perbedaan berat biji yaitu 74,61 g untuk yang terinokulasi dan 53,26 g untuk tanaman kontrol, dari 40 tanaman kedelai yang ditanam di rumah kaca. Hasilinimenunjukkan bahwa tanamanyang terinokulasi A. tumefaciens $\mathrm{LBA}_{4404}$ mampu berproduksi lebih tinggi dari tanaman kontrol yaitu sekitar 39,82\%. Disamping itu juga dilakukan penimbangan secara acak, masing-masing 10 biji ulangan. Hasilnya adalah kedelai transgenik mempunyai berat biji rata-rata 1,099 g. Ini berarti biji kedelai transgenik lebih berat 4,624\% dari biji kedelai non transgenik.

Dengan adanya indikasi biosintesis protein yang kaya sulfur pada biji kedelai, maka ada peluang keberhasilan berekspresinya gen-gen SFA8 ke dalam sel tanaman kedelai (Sunarpi dan Anderson, 1997). Prinsipnya adalah menginokulasi sel-sel meristem atau embrio yang tertransformasi akan tumbuh menjadi tanaman transgenik yang mengandung gen yang tertransformasi melalui vector $A$. tumefaciens. Dalam teknik ini akan lebih banyak menghasilkan tanaman transgenik yang chimera, artinya tidak seluruh tanaman adalah sel yang tertransformasi tetapi transformasi genetik terjadi hanya secara parsial. Namun biasanya $1-2 \%$ dari tanaman yang dihasilkan adalah transgenik penuh (whole transgenic) artinya setiap sel pada tanaman tersebut adalah sel-sel yang tertransformasi (transformed cell) (Wirawan et al., 1998).

\section{Analisis Jaringan Transforman}

Untuk lebih meyakinkan bahwa tanaman kedelai hasil transformasi telah membawa gen albumin, maka dilakukan analisis PCR pada tunas muda kedelai transgenik, menggunakan primer spesifik albumin dari Sfa8. Hasilnya seperti pada Gambar 4.

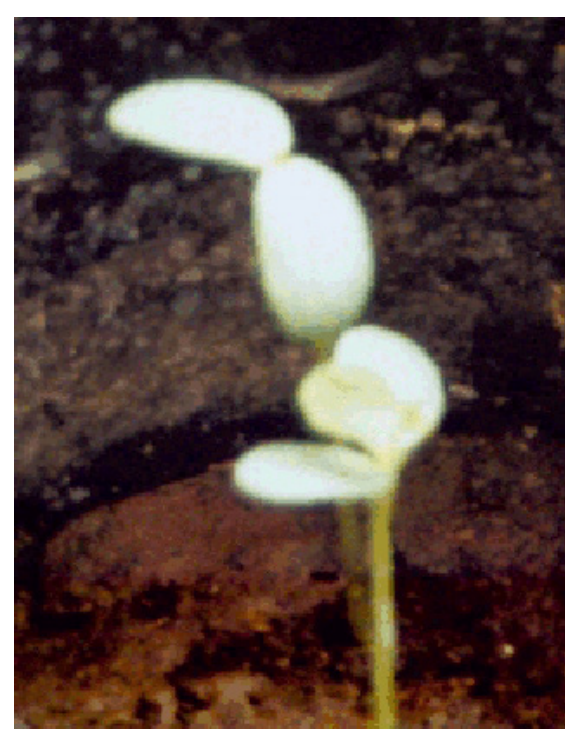

A

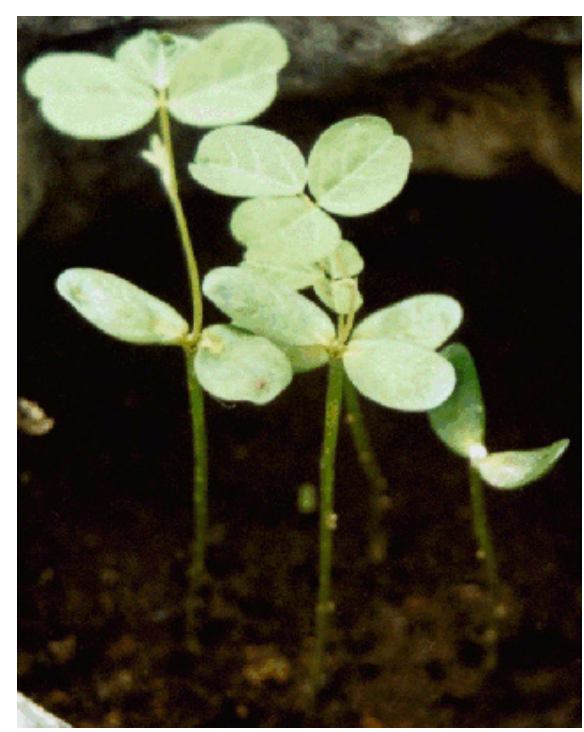

B

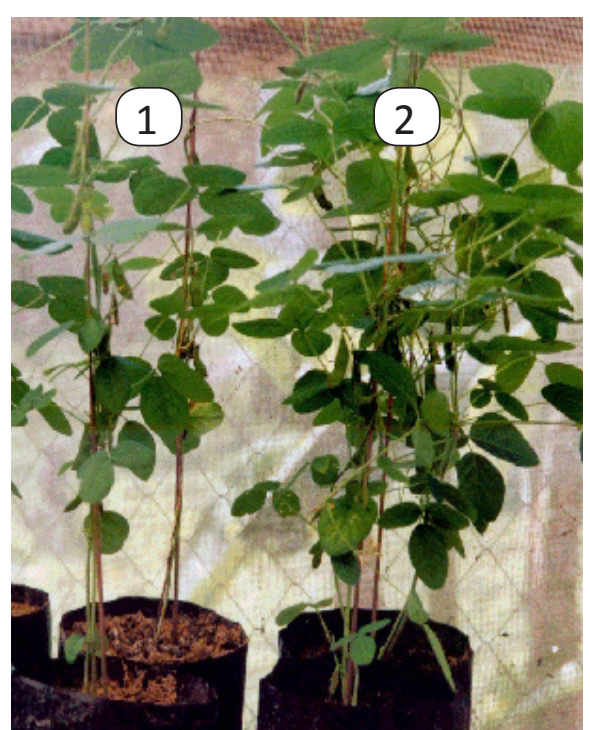

C

Gambar 3. Transformasi gen albumin secara in planta pada tanaman kedelai dengan vector A. tumefaciens LBA $_{4404}$ (A) Bibit kedelai diinokulasi pada bagian meristern di atas kotiledon. (B) Pertumbuhan tunas di atas kotiledon setelah ditransformasi. (C) Tanaman kedelai transgenik yang dihasilkan melalui transformasi in planta. 1. Kontrol (non transformed). 2. Tanaman transgenic dengan percabangan yang banyak, dibandingkan dengan kontrol 


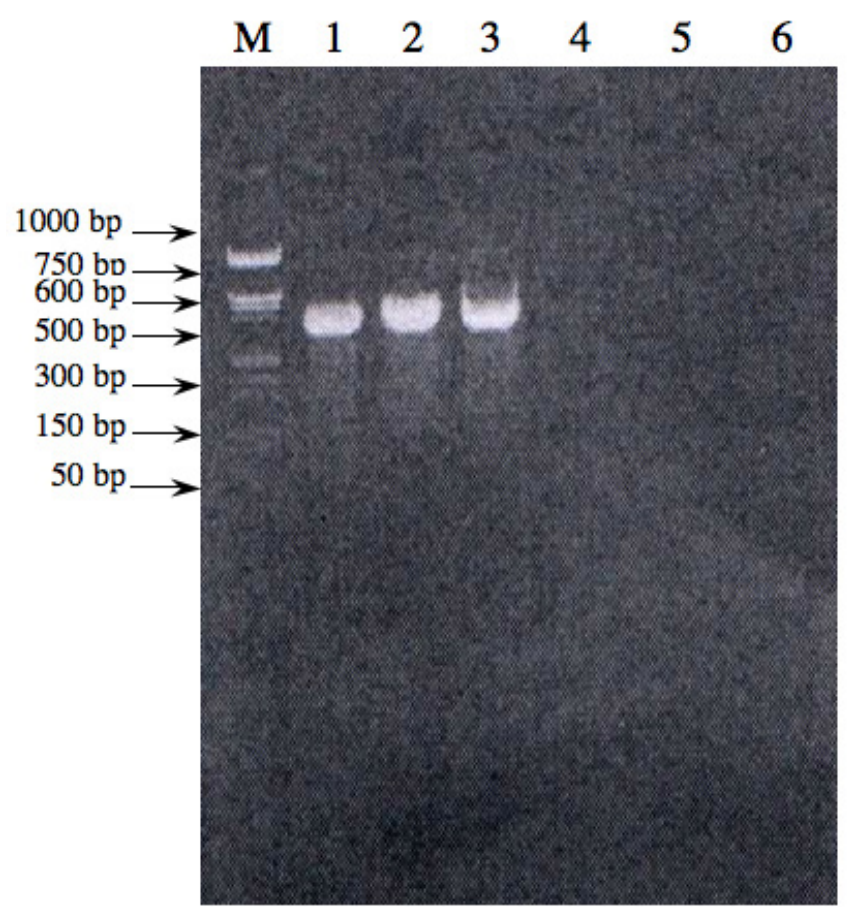

Gambar 4. Deteksi gen albumin bunga matahari pada tunas muda tanaman kedelai transgenik hasil transformasi. lane 1,2,3 merupakan kedelai transgenik dan lane 4,5,6 adalah kedelai non transgenik,, $\mathrm{M}=$ Marker

Dari hasil analisis PCR di atas menunjukkan bahwa tanaman kedelai transgenik (lane 1, 2, 3) mempunyai ukuran DNA 600 bp karena telah membawa gen albumin dari bunga matahari, sedangkan tanaman non transgenik (lane 4,5,6) tidak menghasilkan pita DNA albumin. Perlu diketahui bahwa Sfa8 tidak ada pada tanaman kedelai, sehingga setelah dilakukan uji PCR dengan primer spesifik dari Sfa8, hanya tanaman kedelai yang mengandung albumin yang teramplifikasi, sehingga menghasilkan pita DNA albumin $600 \mathrm{bp}$. Hasil ini didukung oleh penelitian Kort, et al. (1991) yang menyebutkan bahwa isolasi gen SFA8 dari bunga matahari melalui proses PCR menunjukkan ukuran DNA albumin 600 bp. Sedangkan tanaman non transgenik karena tidak mengandung albumin sehingga tidak terjadi amplifikasi dan hasilnya adalah negatif.

\section{SIMPULAN}

Gen albumin bunga matahari (6oo bp) yang diklon pada plasmid vector $\mathrm{pBI}_{121}$ dapat ditransformasikan ke dalam A. tumefaciens LBA $_{4404}$ menggunakan metode triparental mating. Transformasi genetik menggunakan vector $A$. tumefaciens $\mathrm{LBA}_{4404}$ dapat menghasilkan tanaman kedelai transgenik secara in planta.

\section{UCAPAN TERIMA KASIH}

Melalui kesempatan ini penulis menyampaikan terima kasih dan penghargaan yang setinggi-tingginya kepada yang terhormat Bapak Prof. Dr. Ir. I G. P. Wirawan, MSc dan Bapak Dr. Ir. I Made Sudana MS, yang dengan sepenuh hati mencurahkan waktu, tenaga dan pikiran selama berlangsungnya penelitian dan penulisan ini. Bapak Kepala Lab. Bioteknologi Pertanian beserta staf, serta rekan-rekan semuanya sehingga penelitian ini dapat diselesaikan sesuai rencana.

\section{DAFTAR PUSTAKA}

Kort, A.A.J.B. Caldwell. G.G. Lilley, and T.J.V. Higgins, 1991. Amino acid and cDNA sequence of a methionine-rich $2 \mathrm{~S}$ protein from sunflower seed (Helianthus annuus, L.).

Pickaedt, T., Saalbach, I., Waddell, D., Meixner, M., Muntz, K. and Scheider, O., 1993. Seed spesific expression of the $2 \mathrm{~S}$ albumin gene from Brazil nut (Bertholletia excelsa) in transgenic vicia narbonensis. Molecular Breeding 1: 295-301.

Rafigul, M., Khan, I., Cereotti, A., Tabe, L., Aryan, A., McNabb, W., Moore, A., Craig, S., Spancer, D. and Higgins, T.J.V., 1993. Acumulation of sulphur-rich seed albumin from sunflower in the leavesof transgenic subterranean clover (Trifolium subterraneum, L.). Transgenic Research 5: 179-185.

Sunarpi dan Anderson, J. W., 1997, Allocation of 5 in Generative Growth of Soybeen, Plant Physiol. 114; 687-693.

Tabe. L.M., Wardley - Richardson, T., Cereotti, A. Aryan, A., McNabb, W., Moore, A. and Higgins, T.J.V., 1995. A. Biotechnical approach to improvising the nutritive value of alfalfa. J. Anim. Sci 73: 2752-2759.

Wirawan, I.G.P., 1996. Moleculer Mechanism of Crown Gall Tumor Induction by A. tumefaciens. Graduate Course of Biochemical Regulation, Graduate School of Agriculture Sciences Nagoya University, Nagoya. Japan.

Wirawan, I G. P., I N. Arya, dan S. Subandiah, 1998. Isolasi Loci Resisten terhadap CVPD (Citrus Vein Phloem Degeneration) dengan Metode Transformasi Menggunakan A. tumefaciens, Laporan Penelitian tidak dipiblikasikan. 